\title{
Biochemical parameters and nutritional status of surgical patients with gastrointestinal cancer: a literature review
}

\section{Parâmetros bioquímicos e estado nutricional de pacientes cirúrgicos com câncer gastrointestinal: revisão de literatura}

\author{
Daniela Carla Alberti'iD; Rosana Amora Ascarl2; Emanuela Medeiros Schirmer³.
}

\begin{abstract}
A B S T R A C T
This is an integrative literature review with the objective of identifying the relationship between biochemical parameters and the nutritional status of surgical patients with cancer of the gastrointestinal tract, developed in April 2019, encompassing the databases SCOPUS (Elsevier), PubMed Central $(\mathrm{PMC})$, and the Cochrane Virtual Health Library (BVS). We used the terms "Gastrointestinal Neoplasm" AND "Nutritional Status" AND "Blood Chemical Analysis" with the aid of the Academical software after the protocol validation. Out of 147 articles analyzed, seven were included in the review, as they met the inclusion criteria. There were relevant associations between biochemical parameters and nutritional status. Impaired nutritional status can negatively influence the postoperative outcome. The monitoring of interdisciplinary teams can assist in the recovery of these patients and prevent unfavorable outcomes.
\end{abstract}

Keywords: Nutritional Status. Neoplasm. Blood Chemical Analysis. Oncology Service, Hospital. Surgical Oncology.

\section{INTRODUCTION}

C ancer is a set of diseases characterized by the accumulation of progressive and disordered mutations in the genome of a cell ${ }^{1}$. These modifications can occur in special genes, called proto-oncogenes, which are inactive in normal cells. When activated, protooncogenes are converted into oncogenes, responsible for the malignancy of normal cells, called cancer cells².

The interaction between the host's metabolic state, nutritional aspects, physical activity and other environmental exposures throughout life are parameters involved in the protection or susceptibility to the onset of cancer $^{3}$.

It is estimated for Brazil, in each year of the 2020-2022 triennium, the occurrence of 625,000 new cases of cancer. Among the most common cancers are non-melanoma skin cancers, followed by breast and prostate, colon and rectum, lung, and stomach tumors ${ }^{4}$.

The Brazilian Survey of Oncological Nutrition, carried out in 2013 , found that $45.1 \%$ of the evaluated patients had some degree of malnutrition, and in individuals with tumors of the oral cavity, esophagus and stomach, percentages of malnutrition or nutritional risk found ranged from $62.0 \%$ to $84.0 \%$.

Nutritional depletion is a problem commonly found in cancer patients and is associated with an unfavorable outcome. Patients with gastrointestinal tumors undergoing surgical procedures have a high prevalence of malnutrition due to reduced food intake and increased energy expenditure associated with surgical stress, resulting in the deterioration of nutritional status ${ }^{6}$. In this sense, early detection of nutritional changes allows intervention at the right time, preventing the occurrence of morphological and functional alterations ${ }^{5}$.

In general, the nutritional assessment methods used routinely do not consider factors associated with treatment and side effects and with the inflammatory response in cancer patients, especially those with tumors of the upper gastrointestinal tract, which are most severely affected by nutritional and immunological deficiency and by the trauma of major surgical procedures and the

1 - Associação Hospitalar Lenoir Vargas Ferreira (ALVF), Residências em Saúde - Chapecó - SC - Brasil 2 - Universidade do Estado de Santa Catarina (UDESC), Departamento de Enfermagem - Chapecó - SC - Brasil 3 - Clínica Supera, Departamento de Nutrição - Chapecó - SC - Brasil 
repercussions in the postoperative period ${ }^{7}$.

Among the objective means of assessing nutritional condition are biochemical parameters, which allow visualization of changes in nutritional status, with the advantages of confirming nutritional deficiencies, the early identification of nutritional problems before the appearance of clinical signs and/or symptoms of nutritional order, and monitoring of the individual being treated ${ }^{8}$.

The cause and effect relationship between deficient nutritional status and adverse surgical outcomes has been clearly established in the literature. Malnutrition puts the patient at increased risk for infections, anastomosis dehiscence, wound dehiscence and death". In this sense, the question is, "What is the relationship between biochemical parameters and the nutritional status of surgical patients with gastrointestinal tract cancer?".

Patients who are candidates for surgical procedures must have their nutritional status monitored previously, in order to identify those who may develop malnutrition or those who are already hospitalized with this condition ${ }^{10}$.

Considering the aforementioned scenario, knowledge of the biochemical parameters related to the nutritional status of surgical cancer patients is essential to allow nutritional intervention in an early and effective way, aiming to minimize the risk of complications in the postoperative period and to contribute to a better prognosis. To this end, this study aimed to identify the relationship of biochemical parameters with the nutritional status of surgical patients with gastrointestinal tract cancer.

\section{METHODS}

This is an integrative literature review study with qualitative and quantitative analysis of the findings, developed after the validation of an integrative review protocol by two researchers external to the research.

We included the databases SCOPUS (Elsevier), PubMed Central® (PMC) and Cochrane Library: Virtual Health Library (Bireme). We should note that the Cochrane Library includes the bases Medical Literature Analysis and Retrieval System online (MEDLINE), Scientific Eletronic Library Online (SciELO), and the Latin American and Caribbean Literature in Health Sciences (LILACS). We carried out the search in the databases by the association of the terms in Portuguese "Neoplasia Gastrointestinal" AND "Estado Nutricional" AND "Análise Química do Sangue" and, in English, "Gastrointestinal Neoplasm" AND "Nutritional Status" AND "Blood Chemical Analysis", in April 2019, and imported the articles into the Academical software, which assists in the search and organization of scientific articles in qualitative/quantitative studies ${ }^{11}$

Inclusion criteria were scientific articles (experience reports, integrative literature reviews, original articles) published between 2014 and 2019, available electronically, in Portuguese, English and Spanish, free of charge, and addressing the relationship of biochemical parameters with nutritional status in surgical patients with gastrointestinal cancer.

We excluded duplicate articles and those that did not address the relationship between biochemical parameters and the nutritional status of surgical patients with gastrointestinal cancer.

The primary search in the databases took place via the Portal of Papers of the Coordination for the Improvement of Personnel Higher Education (CAPES), with the importation of articles into the Academical software, which resulted in a total of 147 articles distributed according to the flowchart shown in Figure 1.

We read individual titles, abstracts, and keywords, and removed the excluded papers (n-114) from the following steps, with 33 studies remaining for the complete reading. At that time, two researchers performed an independent analysis, excluding studies that did not address the relationship of biochemical parameters with the nutritional status of surgical patients with gastrointestinal cancer, classified as off-topic. That part culminated in the exclusion of 26 more studies. Thus, the final selection resulted in the inclusion of seven articles, which we read again for further analysis.

This study used the Content Analysis technique ${ }^{12}$ to meet the proposed objective and followed three distinct phases, namely, 1) pre-analysis, material exploration and treatment of results, 2) inference, and 3) interpretation.

As this study did not involve human beings, it was not necessary to seek approval from the Ethics in Research Committee. 


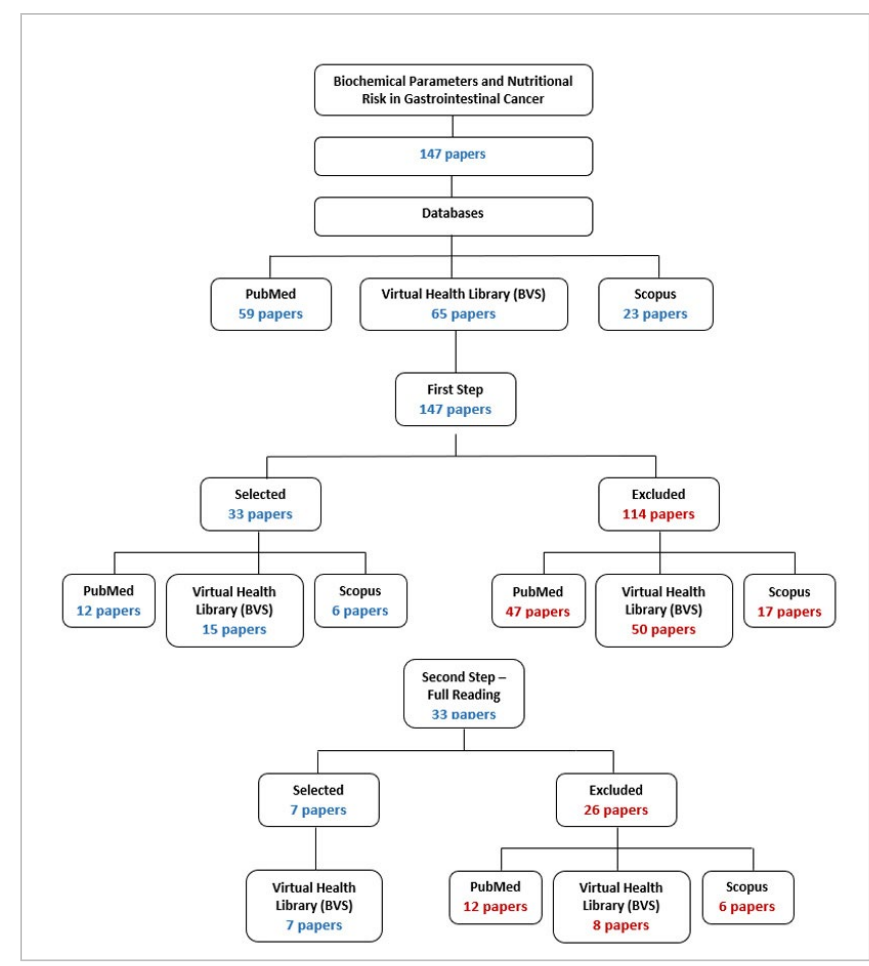

Figure 1. Flowchart of integrative review generated by the Academical software ${ }^{13}$. Source: Academical software (2020).

\section{RESULTS}

\section{Bibliometric analysis}

When analyzing the year of publication, we observed two publications in 2015 and two in 2018. There were no publications in 2019, possibly because the collection occurred until April of that year. We also identified publications in 2014, 2016 and 2017, with one article per year.

There was a diversity of journals in which the various articles were published, since each one was published in a different journal in the area of nutrition.

Regarding the language of publication, most articles ( $n=6,85.7 \%)$ were published in English and one $(n=1,14.3 \%)$, in Spanish. However, one of the articles published in English is also available in Portuguese, strengthening the internationalization of knowledge ${ }^{21}$.

\section{Relationship between biochemical parameters and nutritional status}

It was evident that the Nutritional Inflammatory
Index (NII) ( $p=0.026)$, Adapted Prognostic Inflammatory and Nutritional Index (mPINI) $(p=0.026)$ and Albumin ( $p=0.015$ ) were significantly associated with the categories of the Patient-generated Subjective Global Assessment (PG SGA). However, there was no statistically significant association between PG SGA and the modified Glasgow Prognosis Score (mGPS) markers $(p=0.090)$, Neutrophillymphocyte ratio (NLR) ( $p=0.432)$ and Onodera Prognostic Nutritional Index (mPNI) $(p=0.417)^{14}$.

A study carried out at a university hospital in Vitoria-ES applied PG SGA and found that $71.5 \%$ of the patients had some degree of malnutrition. Of these, $38.6 \%$ were severely malnourished, of whom $58.6 \%$ and $55.7 \%$ had a worse prognosis according to the mGPS and $\mathrm{NII}$, respectively. Hypoalbuminemia and elevated CRP levels were also significantly associated with nutritional status ${ }^{22}$. In this sense, researchers found a significant difference $(p=0.010)$ in the levels of albumin between the three classification groups of the PG-SGA ( $A, B$ and $C$ ). However, the same was not true for transferrin $(p=0.416)$. It is worth mentioning that these parameters were reduced in $97.9 \%$ of the followed patients ${ }^{15}$.

Another study showed statistically significant differences between the mean serum levels of albumin and transferrin in relation to the classification of nutritional status by the AGS, the severely malnourished patients (AGS-C) being those who had the lowest serum levels of albumin and transferrin, followed by the moderately (AGS-B) and the well-nourished (AGS-A) ${ }^{23}$.

The presence of systemic inflammation through serum levels of $C$ Reactive Protein (CRP) was higher $(55.2 \%)$ than PG-SGA (27.6\%), but did not reach statistical difference when associated with the frequency of postoperative complications ${ }^{17}$.

In another study, when comparing clinical laboratory variables with PG-SGA, only hemoglobin was significantly lower in this score's group C. Serum albumin levels, lymphocyte count and CRP values did not reach statistical differences according to PG-SGA ${ }^{20}$.

Researchers observed that albumin showed a positive and significant correlation with PG-SGA scores. However, when compared to the Body Mass Index (BMI), neither albumin nor Total Lymphocyte Count (TLC) showed significant results ${ }^{10}$. In addition, TLC and albumin were associated with the risk of postoperative complications, 
being indicated for monitoring nutritional status and postoperative complications ${ }^{10}$.

Another study showed the association of sarcopenia with the inflammatory response, measured by the high CRP/albumin ratio. This relationship is an independent prognostic marker for recurrence-free survival in patients with esophageal cancer ${ }^{24}$. In that same study, recurrence-free survival was significantly worse in patients with deep tumor invasion, positive lymph node metastasis, high PCR/albumin ratio and high $\mathrm{NLR}^{24}$.

Table 1. Articles that address the relationship between biochemical parameters and the nutritional status of surgical patients with cancer gastrointestinal, Chapecó-SC, Brazil, 2020.

\begin{tabular}{lllll}
\hline \multicolumn{1}{c}{ Title } & \multicolumn{1}{c}{ Authors } & Base & Language & Journal / Year \\
\hline & Fruchtenicht, Ana Valéria & & \\
& Gonçalves; Poziomyck & & \\
Inflammatory and & Aline Kirjner; Reis Audrey & Virtual Health English and & Rev Col Bras \\
nutritional status of patients & Machado dos; Galia Carlos & Library (BVS) & Portuguese & Cir. 2018 \\
submitted to resection of & Roberto; KabkeGeorgia & & \\
gastrointestinal tumors & & & \\
& Brum; Moreira, Luis & & \\
& Fernando &
\end{tabular}

Anemia, nutritional status and inflammatory activity in patients with gastrointestinal tumors in the preoperative phase $^{15}$
Cavalcanti, Rafaella de

Andrade Silva; Burgos, Maria Virtual Health Goretti Pessoa Araújo; Maio, Library (BVS) Regiane
English

Nutr Clin Diet Hosp. 2018
Effects of omega-3 fatty acids on patients undergoing surgery for gastrointestinal malignancy: a systematic review and meta-analysis ${ }^{16}$
Yu Jing; Liu, Lian; Zhang Y, Virtual Health Wei Jia; Yang, Fan Library (BVS)
BMC Cancer 2017

\section{Association Between \\ Nutritional Status, Inflammatory Condition, and Prognostic Indexes with Postoperative Complications and Clinical Outcome of Patients with Gastrointestinal Neoplasia ${ }^{17}$}

Costa, Milena Damasceno de Souza; Melo, Camila Yandara Souza Vieira de; Amorim, Ana Carolina Ribeiro de; Torres, Dilênia Virtual Health Library (BVS) English Nutr Cancer. 2016 de Oliveira Cipriano; Santos

Ana Célia Oliveira dos

Nutritional assessment and screening for malnutrition ${ }^{18}$

\section{Benoist, Stéphane; Brouquet, Antoine}

Virtual Health Library (BVS)
English

J. Visc. Surg 2015
Preoperative nutritional support in cancer patients with no clinical signs of malnutrition--prospective randomized controlled trial ${ }^{19}$
Kabata, Pawel; Jastrzebski, Tomasz; Kakol, Michael; Król, Karolina; Bobowicz, Maciej; Kosowska Anna; Janusz Jaskiewicz.

Virtual Health
Library (BVS) $\quad \begin{gathered}\text { Support. Care } \\ \text { Cancer } 2015\end{gathered}$

Relación entre estado nutricional y evolución postoperatoria, em cirugía oncológica digestiva ${ }^{20}$
Pañella, Loreto; Jara,

Marlene; Cornejo, Morelia; Lastra, Ximena; Contreras, Maria Gladys; Alfaro, Kattia, Virtual Health Library (BVS) English Rev Med Chile. 2014 
Significant results were identified with regard to the Percentage Weight Loss (PWL), which is correlated with serum CRP levels ( $p=0.002)$, CRP/albumin ratio $(p=0.002), P I N I(p=0.002)$ and Glasgow score $(p=0.000) 17$. Likewise, there were statistically significant associations between PWL and the inflammatory markers $\mathrm{NLR}, \mathrm{mPINI}$ and $\mathrm{NII}^{14}$.

In disagreement with this finding, researchers observed the absence of inflammatory activity in the majority of the studied patients, with no significant correlation between serum albumin and CRP25. However, despite the absence of significant correlation, of the five patients evaluated who had an increase in serum CRP concentrations, three had decreased serum albumin values $(\leq 3 \mathrm{~g} / \mathrm{dL})^{25}$.

An intervention group and a control group were followed, the first receiving a hyperprotein supplement in the preoperative period. The researchers found significantly decreased values of all parameters ( $p \leq 0.001$ ) in the control group, values of albumin and weight loss borderline to malnutrition, while in the supplementation group, those levels increased ${ }^{19}$.

An investigation of postoperative patients divided into an intervention group (supplemented with immunomodulatory nutrition) and a control group (without diet change) identified changes between the groups with respect to serum albumin levels, the greatest reduction being found in the control group, $25 \%$, versus $14 \%$ in the intervention group. In addition, the control group displayed higher rates of postoperative complications. The authors stated that preoperative nutritional therapy could be recommended for all patients with preoperative serum albumin levels below $4.5 \mathrm{mg} /$ $\mathrm{dL}^{26}$.

Approximately $65 \%$ of hospitalized patients with digestive cancer showed a reduction in body weight, with a positive correlation between percentage of weight loss and longer hospital stay $(\mathrm{p} \leq 0.001)^{27}$.

Patients who lost $5 \%$ or more of their usual weight had significantly lower values of BMI, Arm Circumference, Muscle Arm Circumference, hemoglobin and albumin ${ }^{20}$.

Unintentional weight loss of more than $10 \%$ in the previous six months or more than $5 \%$ in the last month is the easiest nutritional status indicator to be obtained and can be used to track the largest number of patients, since it is a simple and easy to measure information ${ }^{18}$.

Patients with digestive cancer also showed lower serum albumin levels and higher CRP levels, important markers of nutritional risk and inflammation, respectively ${ }^{27}$.

Significant changes were also observed in the median body weight $(p=<0.001)$, transferrin $(p=0.032)$ and tricipital skin fold $(p=0.05)$. However, the levels of albumin and total protein changed slightly, without statistical significance ${ }^{19}$.

Another analysis showed that the Body Mass Index (BMI), the percentage of muscular area of the arm and the percentage circumference of the calf were significantly lower in patients with sarcopenia. The reduction in muscle mass was present in $69.0 \%$ of the patients, while the loss of muscle strength occurred in $47.2 \%$ of the individuals ${ }^{28}$.

\section{Postoperative complications and nutritional status}

We emphasize that, considering the relationship between nutritional status and postoperative outcome of patients with gastrointestinal cancer, the studies included in this review poorly covered deaths and postoperative complications.

Regarding complications, the association between nutritional status assessed by the PG-SGA and arm circumference and the occurrence of postoperative complications in patients undergoing gastrointestinal tract surgery was confirmed, with eight (73\%) patients with complications having greater PG-SGA scores, but only one $(6 \%)$ patient without postoperative complications displaying the highest PG-SGA score $(p \leq$ $0.001)^{17}$.

Similarly, in a study that evaluated surgical patients admitted to a cancer hospital using PG-SGA and the Nutritional Risk Index (NRI), the percentage of malnourished patients was $56.8 \%$, according to NRI and PG-SGA, and malnutrition correlated with the occurrence of postoperative complications in these patients. In addition, NRI was an indicator of postoperative complications and hospital stay ${ }^{29}$. 
Researchers observed a high risk of postoperative complications represented by changes in mPINI (73\%), as well as a high prevalence of systemic inflammation characterized by altered CRP values, in $70 \%$ of the sample ${ }^{14}$. In this perspective, another study that used the PCR/albumin ratio found that its elevation could be an independent prognostic factor for the overall survival of patients undergoing surgical resection. This indicator was able to predict tumor local recurrence and the appearance of distant metastases in patients with localized mass ${ }^{30}$.

To determine whether preoperative nutritional therapy should be routinely used in patients with gastrointestinal cancer without signs of malnutrition and whether this approach has positive clinical results, a study assessed two groups: an intervention group (standard diet plus hypercaloric and hyperproteic supplementation), and a control group (without changes in the diet's composition) $)^{19}$. The authors found that, although surgical complications occurred in both groups comparatively, those that are potentially associated with nutritional status, such as anastomotic leaks and evisceration, occurred only in patients who did not receive supplementation. The number and severity of postoperative complications also differed between the study groups. The total number of complications was significantly higher in the control group (17 versus eight; $p=0.04)$. When divided into subgroups by severity, these differences were also visible: mild complications, six versus three $(p=0.036)$, and severe ones, 11 versus five $(p<0.001)$. They observed a reduction in the percentage of total complications in patients who received nutritional supplementation compared with the control group (from $35.4 \%$ to $14.8 \%)^{19}$.

Along the same line, nutritional therapy before surgery has been found to favor faster postoperative recovery and reduced hospital costs. The authors consider that patients who are candidates for surgery and who are at nutritional risk may benefit from preoperative nutritional supplementation, with a potential improvement in their immune status after surgery and a consequent reduction in the average cost of hospitalization ${ }^{31}$.

In another investigation, the authors found a slightly lower frequency of complications among patients supplemented in the preoperative period $(15.8 \%$ versus
28\%).However, these findings did not reach statistical significance ${ }^{20}$.

According to the guidelines of clinical nutrition in surgery of the European Society for Clinical Nutrition and Metabolism (ESPEN), the monitoring of the nutritional status must be carried out before and after major operations, recommending the indication of perioperative nutritional therapy in patients with malnutrition and/or nutritional risk ${ }^{32}$.

\section{Postoperative death}

Researchers have identified several parameters related to mortality. The inflammatory state evidenced by high levels of CRP and reduced levels of albumin were associated with an unfavorable clinical outcome and death. The nutritional impairment observed by the PG-SGA also had a significant association with mortality. In addition, the Glasgow Prognosis score and the Inflammatory and Nutritional Prognosis Index were associated with the occurrence of complications and a higher incidence of death ${ }^{17}$.

Similarly, there was a statistically significant association between the three PG-SGA categories and the three categories of the GPS. Significant associations were also identified between the presence of complications and the PG-SGA and, as well as the GPS. However, in this study, only the GPS was a predictor of mortality ${ }^{33}$.

High levels of GPS, a prognostic score based on inflammation, are associated with higher short-term postoperative risks and lower long-term survival in patients with advanced stomach cancer. Notably, patients with GPS of two had a high hospital mortality rate (10\%), while patients with GPS of zero and one displayed in-hospital mortality rates of $1.0 \%$ and $1.5 \%$, respectively $(p=0.006)^{34}$.

Likewise, in the assessment of independent factors associated with death, tumor staging $(p=0.001)$ and albumin $(p=0.004)$ were the only independent predictors of mortality ${ }^{14}$. Regarding NLR, this was the one that most correlated with death, as there were significantly higher NLR values in cases of death $(p=0.033)$. However, after a multivariate analysis, this marker did not remain statistically significant as a predictor of mortality $(p=0.139)^{14}$.

Another study observed data similar to these, finding that the higher the value of the total 
lymphocyte count (TLC), the smaller the number of days of hospitalization. The TLC of the elderly who died was lower than in the patients who were discharged, with a statistically significant result. According to the authors, immunological changes, such as reductions in TLC, increase the frequency and severity of infections and are the cause of mortality associated with malnutrition in surgical patients ${ }^{35}$.

\section{FINAL CONSIDERATIONS}

Biochemical parameters and inflammatory markers are directly related to the nutritional status of surgical patients with gastrointestinal cancer. These associations were verified especially when the nutritional status was determined by the PG-SGA, and by the percentage of weight loss. Negative changes in these indicators have an impact on postoperative recovery and on the follow-up of cancer treatment.

It is advisable that multi-professional teams monitor cancer patients who are candidates for surgical procedures and their indicators of nutritional status, to prevent worsening malnutrition and unfavorable outcomes, facilitating postoperative recovery.

\section{R E S U M O}

Trata-se de revisão integrativa da literatura com o objetivo de identificar a relação dos parâmetros bioquímicos com o estado nutricional de pacientes cirúrgicos com câncer do trato gastrointestinal, desenvolvida em abril de 2019, incluindo as bases de dados SCOPUS (Elsevier), PubMed Central® (PMC) e Biblioteca Cochrane: Biblioteca Virtual em Saúde (BIREME). Utilizou-se a associação dos descritores "Gastrointestinal Neoplasm" AND "Nutritional Status" AND "Blood Chemical Analysis" com o auxílio do Programa Academical após a validação de protocolo. Dos 147 artigos analisados, sete foram incluídos na revisão por atender os critérios de inclusão. Dentre os resultados, evidenciaram-se associações relevantes entre os parâmetros bioquímicos e o estado nutricional. Observou-se que o estado nutricional depauperado pode influenciar negativamente o desfecho pós-operatório. O acompanhamento de equipes interprofissionais pode auxiliar na recuperação desses pacientes e evitar desfechos desfavoráveis.

Palavras chave: Estado Nutricional. Neoplasia. Análise Química do Sangue. Serviço Hospitalar de Oncologia. Oncologia Cirúrgica.

\section{REFERENCES}

1. Instituto Nacional do Câncer. O que é o Câncer [Internet]. Rio de Janeiro; 2020. [acesso em 2020 fev 05]. Disponível em: https://www.inca.gov.br/oque-e-cancer.

2. Ministério da Saúde (Brasil). Instituto Nacional do Câncer. $A B C$ do câncer: abordagens básicas para o controle do câncer. Rio de Janeiro: Ministério da Saúde; 2011. 128 p.

3. Wiseman MJ. Nutrition and cancer: prevention and survival [editorial]. Br J Nutr. 2019;122(5):481-487. Epub 2018 Sep 14.

4. Ministério da Saúde (Brasil). Instituto Nacional do Câncer. Estimativa 2020: incidência de câncer no Brasil. Rio de Janeiro: Ministério da Saúde; 2019.120 p.

5. Ministério da Saúde (Brasil). Instituto Nacional do Câncer. Inquérito brasileiro de nutrição oncológica. Rio de Janeiro: Ministério da Saúde; 2013.136p.

6. Ryu SW, Kim IH. Comparison of different nutritional assessment in detecting malnutrition among gastric cancer patients. World J Gastroenterol. 2010; 16(26):3310-17

7. Poziomyck AK, Fruchtenicht AVG, Kabke GB, Volkweis BS, Antoniazzi JL, Moreira LF. Confiabilidade da avaliação nutricional em pacientes com tumores gastrointestinais. Rev Col Bras Cir. 2016;43(3):18997.

8. Sampaio LR, Silva MCM, Oliveira NA, Souza CLS. Avaliação bioquímica do estado nutricional. In: Sampaio LR, organizadora. Avaliação Nutricional. Salvador: EDUFBA; 2012. p. 49-72.

9. Feig BW, Hsu C. Princípios da oncologia cirúrgica. In: Hoff PMG, editor. Tratado de Oncologia. São Paulo: Atheneu; 2013. p.525-36.

10. Rocha NP, Fortes RC. Contagem total de linfócitos e albumina sérica como preditores de risco nutricional em pacientes cirúrgicos. ABCD Arq Bras Cir Dig. 2015;28(3):193-6.

11. Pontes RF, Rech KCJ, Ascari RA. Aplicação de Nova Tecnologia como Ferramenta para a Pesquisa 
Qualitativa de Revisão Integrativa: Programa Sophie. Rev Enferm UFPE On Line. 2017;11(10):682-85.

12. Bardin L. Análise de Conteúdo. São Paulo: Edições 70; $2011.280 \mathrm{p}$.

13. Pontes RF, Pontes KCJR. Acadêmico. Sistemas Acadêmicos para Pesquisas Científicas Ltda. Chapecó, 2020. Disponível em: https://www. academical.com.br/. Acesso em: 06 fev. 2020.

14. Fruchtenicht AVG, PoziomycK AK, Reis AMD, Galia CR, Kabke GB, Moreira LF. Estado inflamatório e nutricional de pacientes submetidos à ressecção de tumores gastrointestinais. Rev Col Bras Cir. 2018;45(2):e1614.

15. Cavalcanti RAS, Burgos MGPA, Maio, R. Anemia, nutritional status and inflammatory activity in patients with gastrointestinal tumors in the preoperative phase. Nutr Clín Diet Hosp. 2018;38(1):135-41.

16. Yu J, Liu L, Zhang Y, Wei J, Yang F. Effects of omega-3 fatty acids on patients undergoing surgery for gastrointestinal malignancy: a systematic review and meta-analysis. BMC Cancer. 2017;17(1):271.

17. Costa MDS, Melo CYSV, Amorim ACR, Torres DOC, Santos ACO. Association between nutritional status, inflammatory condition, and prognostic indexes with postoperative complications and clinical outcome of patients with gastrointestinal neoplasia. Nutr Cancer. 2016;68(7):1108-14.

18. Benoist S, Brouquet A. Nutritional assessment and screening for malnutrition. J Visc Surg. 2015;152(1):53-7.

19. Kabata P, Jastrzębski T, Kąkol M, Król K, Bobowicz $M$, Kosowska A, et al. Preoperative nutritional support in cancer patients with no clinical signs of malnutrition - prospective randomized controlled trial. Support Care Cancer. 2015; 23(2):365-70.

20. Pañella $L$, Jara $M$, Cornejo $M$, Lastra $X$, Contreras $M G$, Alfaro $K$, et al. Relación entre estado nutricional y evolución postoperatoria, en cirugía oncológica digestiva. Rev Méd Chile. 2014;142(11):1398-406.

21. Fiorin JL. Internacionalização da produção científica: a publicação de trabalhos de Ciências Humanas e Sociais em periódicos internacionais. RBPG. 2007;4(8):263-81.

22. Silva NMF, Barcelos ACL, Noé EP, Cuzzuol JT, Valente KP, Moraes RAG, et al. Associação entre desnutrição, escore prognóstico de Glasgow modificado e índice inflamatório nutricional em pacientes com câncer. Braspen J. 2017;32(3):235-40.

23. Pereira MAC, Santos CA, Brito JA, Fonseca J. Scored patient-generated subjective global assessment, albumin and transferrin for nutritional assessment of gastrostomy fed head or neck cancer patients. Nutr Hosp. 2014;29(2):420-6.

24. Matsunaga $T$, Miyata $H$, Sugimura $K$, Motoori $M$, Asukai $K$, Yanagimoto $Y$, et al. Prognostic significance of sarcopenia and systemic inflammatory response in patients with esophageal cancer. Anticancer Res. 2019;39(1):449-58.

25. Maio R, Berto JC, Corrêa CR, Campana AO, Paiva SAR. Estado nutricional e atividade inflamatória no pré-operatório em pacientes com cânceres da cavidade oral e da orofaringe. Rev Bras Cancerol. 2009;55(4):345-53.

26. Kaya SO, Akcam TI, Ceylan KC, Samancilar O, Ozturk $\mathrm{O}$, Usluer O. Is preoperative protein-rich nutrition effective on postoperative outcome in non-small cell lung cancer surgery? A prospective randomized study. J Cardiothorac Surg. 2016;11:14.

27. Coruja MK, Steemburgo T. Estado nutricional e tempo de internação de pacientes adultos hospitalizados com diferentes tipos de câncer. Braspen J. 2017;32(2):114-8.

28. Onishi S, Shiraki M, Nishimura K, Hanai T, Moriwaki $\mathrm{H}$, Shimizu M. Prevalence of sarcopenia and its relationship with nutritional state and quality of life in patients with digestive diseases. J Nutr Sci Vitaminol. 2018;64(6):445-53.

29. Fugolar F, Hacke A, Polakowski CB, Kato M. Relação do índice de risco nutricional com complicações pós-operatórias de cirurgias do sistema digestório em um hospital oncológico. Nutr Clín Diet Hosp. 2016;36(4):34-40.

30. Gao J, Agizamhan S, Zhao X, Jiang B, Qin H, Chen $M$, et al. Preoperative C-reactive protein/albumin ratio predicts outcome of surgical papillary renal cell carcinoma. Future Oncol. 2019;15(13):1459-68.

31. Wang R, Cai H, Li Y, Chen C, Cui Y. Impact exerted by nutritional risk screening on clinical outcome of patients with esophageal cancer. Biomed Res Int [Internet]. 2018 Mar [citado 2019 Nov 23]; 
2018:7894084. Disponível em: https://www. ncbi.nlm.nih.gov/pmc/articles/PMC5892299/pdf/ BMRI2018-7894084.pdf.

32. Weimann A, Braga M, Carli F, Higashiguchi $T$, Hübner $M$, Klek $S$, et al. ESPEN guideline: Clinical nutrition in surgery. Clin Nutr. 2017;36:623-50.

33. Silva JB, Maurício SF, Bering T, Correia MI. The relationship between nutritional status and the Glasgow prognostic score in patients with cancer of the esophagus and stomach. Nutr Cancer.

Received in: 26/02/2020

Accepted for publication: 09/04/2020

Conflict of interest: no.

Funding source: none.
2013;65(1):25-33.

34. Hsueh SW, Liu KH, Hung CY, Cuo YC, Tsai CY, Hsu $J$, et al. Significance of the Glasgow Prognostic Score in predicting the postoperative outcome of patients with stage III gastric cancer. J Clin Med. 2019;8(9):1448.

35. Lima FCA, Waisberg J, Silva MLN. Gerenciamento nutricional: relação de parâmetros nutricionais, tempo de internação e mortalidade em pacientes cirúrgicos. Braspen J. 2016;31(4):293-98.

Mailing address:

Daniela Carla Alberti

E-mail: danielaalberti1@hotmail.com

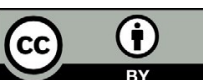

